\title{
Earthquake Vulnerability in West Nusa Tenggara: Risk Perception, Previous Experience and Preparedness
}

\author{
Alifurriza Qurnia Septia \\ Department of Social Studies \\ Universitas Negeri Yogyakarta \\ Yogyakarta, Indonesia \\ alifurriza.2017@student.uny.ac.id
}

\author{
Setyabudi Indartono \\ Faculty of Economy \\ Universitas Negeri Yogyakarta \\ Yogyakarta, Indonesia \\ Setyabudi_indartono@uny.ac.id
}

\begin{abstract}
Indonesia is a disaster-prone country. It is proven by the occurrence of various disasters that continuously affect various regions, whether it is caused by natural factors (earthquakes, tsunami, floods, volcanic eruptions, landslides, hurricanes, etc.), or by non-natural factors such as various consequences of technological failure and human activity. Generally, the disasters that occur causing suffering to the community, both in the form of human loss of property and damage to the environment and the destruction of the results of development achieved. Earthquake disaster potential affecting West Nusa Tenggara Island consists of 2 parts, namely the Indo-Australian subduction zone in the south of West Nusa Tenggara and a back arc thrust in the north of West Nusa Tenggara. Therefore, the frequency of earthquake events in West Nusa Tenggara is high. One of these efforts is to reduce the level of social vulnerability. Social vulnerability is often forgotten in the earthquake disaster management process, some activities are more often focused on efforts to knowledge of building structures and physical problems. Social vulnerability analysis is the state of an area that is affected by physical, social, cultural, and environment to prevent, reduce in response to disasters. Earthquakes are natural disasters that cannot be predicted when they occur accurately, so there needs to be an effort to minimize the vulnerability of the community.
\end{abstract}

Keywords-Earthquake, West Nusa Tenggara, Vulnerability, Preparedness

\section{INTRODUCTION}

Indonesia is a meeting point between the three major plates of the world, namely the Pacific Plate, the Eurasia Plate, and the Indian-Australian Plate commonly called Triple Junction. The HindiaAustralia Plate Movement annually is about $7 \mathrm{~cm}$ to the north and the Pacific Plate is about $12 \mathrm{~cm}$ each year to the southwest [1]. The impact of the movement of the triple junction plate causes the Indonesian archipelago to have a high level of earthquake so that it is prone to have tectonic earthquakes. The territory of Indonesia is also very rich with active fault distribution or active faults. There are more than 200 that have been mapped well and there are still many that have not been mapped so it is not surprising that the territory of Indonesia in that day was more than 10 earthquakes that occurred [2]. A number of these active faults are the large Sumatra fault that divides Aceh to Lampung, faults active in Java, Lembang,
Jogjakarta, in northern Bali, Lombok, West Nusa Tenggara, East Nusa Tenggara, Sumbawa, in Sulawesi, Sorong, Memberamo, in addition to Kalimantan.

Based on the potential disaster and the level of vulnerability that exists, it can be estimated that the risk of disasters that will occur in the Indonesian region is high. Social vulnerability indicates an estimated level of vulnerability to the safety of the life / health of the population if there is a danger [3]. This increase will be more influenced if the government apparatus and the community are not aware of and responsive to the potential for natural disasters in their area. While other factors that encourage higher risk of disasters are public choice [4] [5]. Many residents choose or intentionally live in areas that are vulnerable to disasters with various reasons such as soil fertility, or other opportunities promised by the location. With the potential threats from earthquake occurrence and potential vulnerability of population factors as well as high disaster risk index values, there is a need for disaster risk mapping at the level of disaster risk assessment in West Nusa Tenggara so that mitigation efforts can be performed effectively, efficiently and on target in the regions with high risk. Therefore, comprehensive efforts are needed to reduce the risk of natural disasters, among others by conducting disaster mitigation efforts. Disaster management which used to be more focused on post-disaster management needs to be diverted to vulnerability reduction and capacity building activities [6]. Earthquakes that occur in the West Nusa Tenggara region, especially the island of Lombok, do not rule out the possibility of recurrence. Earthquake disasters occur suddenly and are difficult to predict. The community must absolutely can deal with earthquake disasters, including knowing the area of disaster zones. Various factors that influence one's alertness and preparedness to disasters include knowledge of hazards, previous experiences of disasters, and attempts to react [7].

\section{WEST NUSA TENGGARA EARTHQUAKE}

Geologically, from the existing slabs and faults, an earthquake will certainly occur in Indonesia. The Indonesian region has the potential to experience earthquakes because of its position at the confluence 
of three of the world's main plates, namely Eurasia, Indonesia and the Pacific. From this collision, there are about six active plate collisions which have the potential to trigger strong earthquakes. Indonesia's position is known to be on the Pacific Ring of Fire (Ring of Fire) which is a 'horseshoe' area of 40,000 $\mathrm{km}$ that often experiences earthquakes and volcanic eruptions that surround the Pacific Ocean basin [8] About $90 \%$ of earthquakes occur and $81 \%$ of the largest earthquakes occur along this Ring of Fire. An earthquake measuring 7 on the Richter scale that rocked the island of Lombok, West Nusa Tenggara and the surrounding region occurred on Sunday (05/08/2018). Head of Public Relations of the Meteorology, Climatology and Geophysics Agency, Harry Tirto Djatmiko stated, the 7 SR earthquake was centered on land, namely precisely at the point 8.37 LS and $116.48 \mathrm{BT}$ at a depth of $15 \mathrm{~km}$. However, the earthquake broke out to the sea. It can cause a tsunami. In addition, the earthquake was included in the category of shallow earthquakes. This earthquake was called the main earthquake in a series of earthquakes that rocked the Lombok region, West Nusa Tenggara. Previously, a magnitude 6.4 earthquake shook North Lombok on July 29, 2018 [9].

In 2017, Indonesia has revised the seismic hazard map where all regions have been zoned and quantified related to how much potential seismic shocks are. Based on the map, a civilian expert should be able to design earthquake resistant structures that are suitable for all regions in Indonesia [10]. If everyone follows and obeys the rules that are in place when building a building, then a potential threat can cause damage, loss of human life or environmental damage can be avoided. However, the question arises is why people remain victims of an earthquake with high technology and zoning readiness. It is due to a lack of understanding of the community and the community who do not know about information about the threat of earthquakes in their area. The community also does not know how to cope with an earthquake [11].

\section{VULNERABILITY AND PREPAREDNESS}

Disaster definition in the Disaster Management book - A Disaster Manager's Handbook is an event, natural or man-made, sudden or progressive, which has a powerful impact so that affected communities must respond with external actions ordinarily [12]. According to Law No. 24 of 2007 concerning Disaster Management Chapter I Article I paragraph 1, Disaster is an event or series of events that threaten and disrupt people's lives and livelihoods caused by both natural and / or non-natural and human factors resulting in human lives, environmental damage, property losses, and psychological impact [13].

Vulnerability is a series of conditions that determine whether hazards (both natural hazards and dangers of artificial) which occur can lead to disaster or not. A series of conditions generally can be in the form of physical, social and attitudinal conditions that affect the ability of the community to prevent, mitigate, prepare and respond to the impacts of hazards. Types of vulnerabilities :

1. Physical vulnerability : Building, Infrastructure, Weak construction

2. Social vulnerability : Poverty, Environment, Conflict, high growth rates, children and women, the elderly.

3. Mental Vulnerability : Ignorance, unawareness, lack of confidence, and others. [5]

Urban vulnerability to natural hazards such as earthquakes is a function of human habits. It illustrates the extent to which socioeconomic systems and physical assets in urban areas are vulnerable or resistant to natural hazards. Over the past two decades, vulnerability has become an essential concept in hazard research and in the development of mitigation strategies at the local, national and international levels [14] [15] [16] [17]. Several models of urban vulnerability have been proposed to address the various ways in which communities are subject to the impact of hazards [18]. The concept of human / natural interaction is really rooted in the heart of these models representing natural hazards as dynamic phenomena that involve people not only as victims but also as contributors and modifiers [19]. Because this interaction shows a strong spatial component, urban vulnerability is an inherent spatial problem because it almost always relates to the community in the specified city space.

Preparedness is the activities and steps taken before the occurrence of natural hazards to predict and remind people of the possibility of the occurrence of a hazard, evacuate people and property if they are threatened and to ensure an effective response, for example by stacking foodstuffs [20]. In the disaster management cycle, preparedness efforts are included in the risk reduction phase before a disaster occurs. Shifting the concept of disaster management into a paradigm of disaster risk reduction increasingly emphasizes that disaster preparedness efforts are one of the important steps to reduce the magnitude of losses arising from disasters.

TABLE I. FRAMEWORK FOR INDIVIDUAL AND HOUSEHOLD PREPAREDNESS IN ANTICIPATING NATURAL DISASTERS BASED ON LIPI-UNESCO/ISDR

\begin{tabular}{|c|c|c|}
\hline Parameter & Variable & Indicator \\
\hline $\begin{array}{l}\text { Knowledge } \\
\text { and attitude }\end{array}$ & $\begin{array}{l}\text { Knowledge: } \\
\text { - Alan and } \\
\text { disaster events } \\
\text { (type, source, } \\
\text { magnitude, } \\
\text { location) } \\
\text { - Physical } \\
\text { vulnerability } \\
\text { (location, } \\
\text { condition of } \\
\text { critical facilities, } \\
\text { building } \\
\text { standards) } \\
\end{array}$ & $\begin{array}{l}\text { - Mention the } \\
\text { meaning of natural } \\
\text { disasters, types of } \\
\text { natural events that } \\
\text { cause disasters, } \\
\text { causes, } \\
\text { characteristics and } \\
\text { rescue actions in the } \\
\text { event of a disaster. } \\
\text { - Mention the } \\
\text { characteristics of } \\
\text { buildings resistant to } \\
\text { earthquakes and }\end{array}$ \\
\hline
\end{tabular}




\begin{tabular}{|c|c|c|}
\hline & & tsunamis \\
\hline & $\begin{array}{l}\text { Attitude to } \\
\text { disaster risk }\end{array}$ & $\begin{array}{l}\text { - Family motivation } \\
\text { for preparedness in } \\
\text { anticipating natural } \\
\text { events that cause } \\
\text { disasters }\end{array}$ \\
\hline Policy & $\begin{array}{l}\text { Family policy for } \\
\text { disaster } \\
\text { preparedness }\end{array}$ & $\begin{array}{l}\text { - Family agreement } \\
\text { regarding evacuation } \\
\text { place in an } \\
\text { emergency. } \\
\text { - Family agreement to } \\
\text { do or participate in } \\
\text { evacuation } \\
\text { simulations. }\end{array}$ \\
\hline & $\begin{array}{l}\text { Family plans to } \\
\text { respond to } \\
\text { emergencies }\end{array}$ & $\begin{array}{l}\text { - The existence of a } \\
\text { family rescue plan } \\
\text { (who does what) } \\
\text { when an emergency } \\
\text { occurs. } \\
\text { The presence of } \\
\text { family members } \\
\text { who know what to } \\
\text { do for evacuation. }\end{array}$ \\
\hline $\begin{array}{l}\text { Emergency } \\
\text { response } \\
\text { plan }\end{array}$ & Evacuation plan & $\begin{array}{l}\text { - Availability of } \\
\text { maps, places, family } \\
\text { evacuation routes, } \\
\text { family gatherings. } \\
\text { - The presence of } \\
\text { relatives / friends / } \\
\text { peers who provide } \\
\text { temporary shelter in } \\
\text { an emergency. }\end{array}$ \\
\hline & $\begin{array}{l}\text { First aid, rescue, } \\
\text { safety and } \\
\text { security }\end{array}$ & $\begin{array}{l}\text { - Availability of first } \\
\text { aid kits or essential } \\
\text { medicines for family } \\
\text { first aid. } \\
\text { - There are plans for } \\
\text { family rescue and } \\
\text { safety. } \\
\text { - The presence of } \\
\text { family members } \\
\text { who take part in } \\
\text { training and } \\
\text { evacuation skills. } \\
\text { - Access to } \\
\text { emergency } \\
\text { situations. }\end{array}$ \\
\hline & $\begin{array}{l}\text { Meeting basic } \\
\text { needs }\end{array}$ & $\begin{array}{l}\text { - Availability of basic } \\
\text { needs for } \\
\text { emergencies (eg } \\
\text { ready-to-eat foods, } \\
\text { drinks, flashlights } \\
\text { and batteries). } \\
\text { - Availability of } \\
\text { alternative family } \\
\text { communication } \\
\text { devices (HP / radio / } \\
\text { HT). } \\
\text { - Availability of } \\
\text { alternative lighting }\end{array}$ \\
\hline
\end{tabular}

\begin{tabular}{|c|c|c|}
\hline & & $\begin{array}{l}\text { for families during } \\
\text { emergencies } \\
\text { (flashlight / lamp / } \\
\text { generator) }\end{array}$ \\
\hline & $\begin{array}{l}\text { Equipment and } \\
\text { supplies }\end{array}$ & $\begin{array}{l}\text { Availability of disaster } \\
\text { preparedness bags and } \\
\text { equipment }\end{array}$ \\
\hline & $\begin{array}{l}\text { Important } \\
\text { facilities (hospital, } \\
\text { fire department, } \\
\text { police, Municipal } \\
\text { Waterworks, State } \\
\text { Electricity } \\
\text { Enterprise, } \\
\text { Telkom) }\end{array}$ & $\begin{array}{l}\text { Availability of } \\
\text { address / number } \\
\text { call of a hospital, } \\
\text { fire department, } \\
\text { police, Municipal } \\
\text { Waterworks, } \\
\text { Electricity } \\
\text { Enterprise, Telkom. } \\
\text { Access to important } \\
\text { facilities. }\end{array}$ \\
\hline & $\begin{array}{l}\text { Exercise and } \\
\text { simulation / } \\
\text { rehearsal }\end{array}$ & $\begin{array}{l}\text { - There is an access to } \\
\text { education and } \\
\text { materials for disaster } \\
\text { preparedness. } \\
\text { - Frequency of } \\
\text { exercise (public and } \\
\text { in the household) }\end{array}$ \\
\hline \multirow{4}{*}{$\begin{array}{l}\text { Disaster } \\
\text { warning } \\
\text { system }\end{array}$} & Local traditional & $\begin{array}{l}\text { Availability of } \\
\text { information sources } \\
\text { for disaster warnings } \\
\text { from both traditional } \\
\text { and local sources. }\end{array}$ \\
\hline & $\begin{array}{l}\text { Technology } \\
\text { (signs, signals, } \\
\text { standards) }\end{array}$ & $\begin{array}{l}\text { Availability of } \\
\text { information sources } \\
\text { for technology-based } \\
\text { disaster warnings. }\end{array}$ \\
\hline & $\begin{array}{l}\text { Dissemination of } \\
\text { warnings and } \\
\text { mechanisms }\end{array}$ & $\begin{array}{l}\text { Access to information } \\
\text { on disaster warnings. }\end{array}$ \\
\hline & $\begin{array}{l}\text { Exercise and } \\
\text { simulation }\end{array}$ & Frequency of exercise. \\
\hline \multirow{4}{*}{$\begin{array}{c}\text { Resource } \\
\text { mobilization }\end{array}$} & Human Resources & $\begin{array}{l}\text { The presence of } \\
\text { family members } \\
\text { involved in seminars / } \\
\text { workshops / disaster } \\
\text { preparedness meetings } \\
\text { / training. }\end{array}$ \\
\hline & $\begin{array}{l}\text { Technical } \\
\text { guidance and } \\
\text { material provision }\end{array}$ & $\begin{array}{l}\text { - Availability of } \\
\text { disaster } \\
\text { preparedness } \\
\text { material. } \\
\text { - The skills of family } \\
\text { members related to } \\
\text { disaster } \\
\text { preparedness. } \\
\end{array}$ \\
\hline & Funding & $\begin{array}{l}\text { The allocation of } \\
\text { funds / savings / } \\
\text { investment / insurance } \\
\text { related to disaster } \\
\text { preparedness. }\end{array}$ \\
\hline & $\begin{array}{l}\text { Monitoring and } \\
\text { evaluation }\end{array}$ & $\begin{array}{l}\text { Family agreement to } \\
\text { conduct simulation } \\
\text { exercises and monitor } \\
\text { disaster alert bags } \\
\text { regularly. }\end{array}$ \\
\hline
\end{tabular}

Source: LIPI-UNESCO/ISDR Community Preparedness Assessment, 2006. 


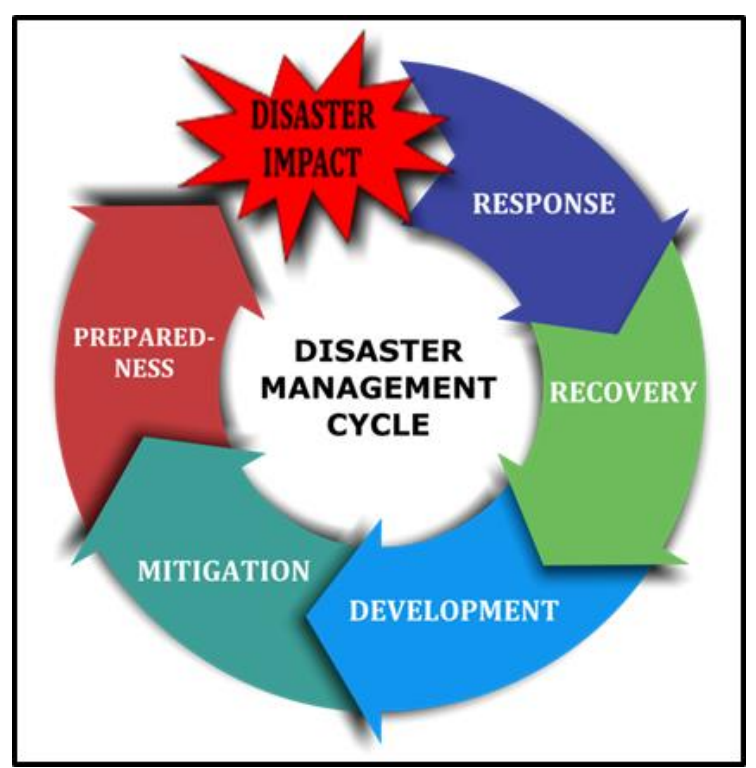

Fig. 1. Disaster management cycle [12]

According to Article 45 of Law Number 24/2007, preparedness efforts are conducted through the following matters: preparation and trial of disaster emergency response plans; organizing, installing and testing early warning systems; supply and preparation of supply goods to fulfill basic needs; organizing, counseling, training and rehearsals on emergency response mechanisms; preparing evacuation sites; preparation of accurate data, information, and updating of the procedures for disaster emergency response; and provision and preparation of materials, goods and equipment to fulfill the recovery of infrastructure and facilities.

Preparedness efforts at the above points are not only done by the government but it can also be done by individuals or communities. It differentiates preparedness efforts from other pre-disaster risk reduction efforts (mitigation and early warning), where preparedness efforts can be done by individuals or communities, while mitigation and early warning efforts are directed primarily from higher levels of management such as government. By striving for preparedness in the community, it also prepares the community not to be too panicked when a disaster occurs so that losses can be reduced to the smallest possible extent. People who are alert have the following characteristics: knowing what to do when a disaster occurs; the level of risk experienced is low; post-disaster recovery rates are fast; have a network that can be used for recovery [22].

\section{EFFORTS TO REDUCE DISASTER RISK}

Disaster risk (Risk) is a potential loss caused by a disaster in an area and a certain period of time which can be in the form of death, injury, illness, threatened life, loss of security, evacuation, damage or loss of property, and disruption of community activities due to a combination of danger, vulnerability and the capacity of the region concerned.
Based on Law Number 24 of 2007 concerning Disaster Management, preparedness is a series of activities done to anticipate disasters through organizing and through effective and efficient measures.

The indicators that will be used to assess community preparedness are derived from five parameters that according to LIPI-UNESCO/ISDR [21] are critical factors for preparedness to anticipate natural disasters, especially earthquakes and tsunami, namely: knowledge and attitudes towards disaster risk; policies and guidelines; plans for disaster emergencies; disaster warning system; and the ability to mobilize resources. By LIPI-UNESCO/ISDR, the five critical preparedness factors are derived into variables which are then further reduced into several indicators that can be used to measure community preparedness in the disaster study area.

Calculating disaster risk in an area based on hazard assessment, vulnerability and capacity in disaster risk using the following equation:

$$
\text { Risk }(\mathrm{R})=\mathrm{H} \times \mathrm{V} / \mathrm{C}(8)
$$

Information:

R: Disaster Risk

H: Danger

V: Vulnerability

C: Capacity

After doing disaster risk, all we have to do is take action to reduce the risk of disaster. Actions taken aiming at vulnerability and increase the capacity of an area.

Activities that can be done aim to reduce disaster risk, among others

1. Relocation of residents from disaster-prone areas, for example moving residents who are on the edge of cliffs that are prone to landslides

2. Disaster preparedness training for residents in an area.

3. Conditioning of houses or public facilities that respond to disasters.

4. The building is relatively stronger if hit by an earthquake.

5. Creation and dissemination of local wisdom about disaster.

Threat is an event or occurrence that has the potential to cause damage, loss of human life or environmental damage. The effective thing that can be done by the government and the community is to do mitigation efforts by knowing the causes of earthquake hazard. The study of social vulnerability to earthquake hazards needs to be done to reduce the impact of losses due to earthquakes. Society is an important element in measuring the risk of a disaster event [23]. The high and low risk of a community due to an earthquake is influenced by the level of vulnerability of the community. There are four types of vulnerabilities, namely physical, social, economic and environmental vulnerabilities. The social 
vulnerability of the community must receive important attention to reduce the risk of earthquakes. Earthquakes to date are natural disasters that cannot be predicted when they occur accurately, so there is a need to reduce the vulnerability of the community. One of these efforts is to reduce the level of social vulnerability. Social vulnerability is often forgotten in the earthquake disaster management process, some activities are more often focused on efforts to knowledge of building structures and physical problems [24].

Especially in the case of earthquakes caused by earthquakes, for example, as an illustration of the results of research and studies of several experts shows that during the 25 years of earthquake events in Indonesia, disaster victims were more caused by damage to simple home buildings such as falling roofs, collapsing columns, destruction of walls, etc. It shows that earthquake mitigation efforts through the development of earthquake resistant housing designs have not been fully successful. This loss does not include losses suffered by the community directly. Both mental and material losses arising from various disasters are not a small amount. It must begin to become a concern and thought for the government and society. In this study, earthquake risk analysis in an area in Indonesia will be analyzed and the author chooses the province of West Nusa Tenggara (NTB) based on seismic potential, history of destructive earthquakes and from the Indonesian Disaster Risk Index for West Nusa Tenggara region.

Based on the standards of post-disaster handling, evacuation, rehabilitation and reconstruction actions are generally done at the disaster site [25]. The evacuation phase is a series of activities to remove victims from disaster locations to new and safer location. This stage is not only to move survivors to safer places, but also to take dead victims to more accessible places. The evacuation phase is generally done by parties who are experienced in this matter, such as the SAR Team, PMI, IRC, Army / Police, MOSA, NGOs and volunteers. In the evacuation process, usually the most needed are health infrastructure, transportation, communication and temporary shelter. While the rehabilitation phase, which is generally done one week after the disaster, is a series of actions towards physical improvement at the disaster site, such as revamping vital roadways, procuring transportation and communication equipment, and adding temporary shelter infrastructure suggestions. At this stage, in addition to actions to improve physical or building, there are also actions that are directed towards mental or psychological improvement of the affected people. Communities affected by disasters are generally still shocked and unstable in facing their daily lives. The parties who assist this stage are usually still the same as the evacuation stage but are added by several community leaders, religious leaders, community leaders, families and so on, in order to build enthusiasm (psychological improvement).

The method used is like the design and build model in the world of construction services, namely while designing while working. It must be done because conditions in the field require fast and effective handling. The main steps in community service are divided into 3 types, namely

1. preparation;

2. implementation; and

3. improvements in the field. [8]

The first step is in the form of a series of coordination activities, survey and licensing activities, and procurement of facilities and infrastructure (initial logistics). The second stage is in the form of a series of field activities, namely the creation of a post, improvement of infrastructure, dissemination of information, collection and distribution of logistics / donors, improvement of the built environment (rehabilitation). The third step is the improvement steps when in the field, namely the implementation of try and error models. Community service activities in the form of post-disaster management are expected to continue even though the pioneer has been completed in the field. Activities will be continued by the government or even from the community's self-help so that the socio-economic life can gradually recover.

\section{CONCLUSION AND PRACTICAL IMPLICATIONS}

A very broad scope for people who are threatened by disasters requires an integrated effort to reduce disaster risk. Substantially, it is an effort to create a disaster-aware and responsive society through education in Disaster Risk Reduction (DRR). The concept of DRR solutions is adjusted to the occurrence of disasters, pre-disaster, disaster, and post-disaster cycles as can be seen in the figure [26]. The stages of implementation of the solution are adjusted to the characteristics of the stages of the disaster cycle.

- During a disaster, activity is tight in an emergency.

- After a disaster, reduce the complexity of complex complications in reconstruction and rehabilitation.

- Pre-disaster need comprehensive planning. Communities threatened with disasters are very diverse. For those who have been educated or who have not been touched by formal education, they need to understand the importance of disaster risk reduction (DRR). The most strategic way for DRR education is needed through formal and informal education channels [28].

Cycles describing disasters will never stop. With empirical data, some disasters can be expected to come again, such as floods and landslides every rainy season will occur. Tsunami will also happen again. However, there is no technology that can detect accurately when an earthquake will come. Tsunami 
that occurs before an earthquake can be detected when they reach the coast because the speed of the earthquake wave is higher. For example, the tsunami in Mentawai came to shore 25 minutes after an earthquake of 7.2 on the Richter Scale at $78 \mathrm{~km}$ southwest of South Pagai Island, Mentawai. The epicenter depth or epicenter of the earthquake is 10 $\mathrm{km}$, with a tsunami wave height of 4-6 m reaching 600 meters from the coastline. It was recorded that the death toll was 413 people, 270 people were seriously injured and 163 were missing [8]. The duration of time between the arrival of the earthquake and the arrival of the tsunami is an opportunity for evacuation of the population in avoiding the tsunami hazard.

\section{RECOMMENDATION}

Based on the results of the discussions that have been conducted, it is recommended for all NTB residents to continue to reduce the impact of severe earthquake disasters through the comprehensive efforts to reduce the risk of natural disasters, and others by undertaking disaster mitigation efforts. Disaster management which used to be more focused on emergency situations needs to be diverted to activities and capacity building. Then it could also be by developing earthquake resistant house designs

\section{REFERENCES}

[1] R. Kurniawan, "Pemetaan Ground Acceleration Menggunakan Metodeprobabilistic Seismic Hazard Analysis Di Propinsi Nusa Tenggara Baratpada Zona Megathrust", Seminar Nasional Teknologi Informasi dan Kedirgantaraan (SENATIK) Vol. III, 21 Desember 2017. P-ISSN: 23373881, E-ISSN: 2528-1666 DOI http://dx.doi.org/10.28989/senatik.v3i0.114. 2017

[2] Badan Meteorologi, Klimatologi, Dan Geofisika (BMKG). https://www.bmkg.go.id/press-release/?p=gempa-lombokberpotensi-tsunami-bmkg-jauhi-bibir-pantai\&tag=pressrelease\&lang=ID Diakses 28 September 2018.

[3] E. Beck, C. Stephen, C. J. Ludvina, A. Carine, and M. Saikali, "Vulnerability to earthquake of Beirut residents (Lebanon): perception, knowledge, and protection strategies" Journal of Risk Research DOI: 10.1080/13669877.2018.1466826. 2018.

[4] S. L. Cutter, "Societal Vulnerability to Environmental Hazards", International Social Science Journal 47 (4): 525 536. 1996.

[5] F. Fatemi, A. Ardalan, B. Aguirre, N. Mansouri, and I. Mohammadfam, "Social Vulnerability Indicators in Disasters: Findings from a Systematic Review", International Journal of Disaster Risk Reduction, PII: S22124209(16)30274-6

DOI: http://dx.doi.org/10.1016/j.ijdrr.2016.09.006. 2016

[6] Alexander, et al. "Global observed changes in daily climate extreme of temperature and precipitation”, J. Geogpy, Res. 111. 2006.

[7] W. Enders, “Applied Econometric Time Series", John Wiley and Sons, inc, 1995.

[8] Qomarun, "Model Complement and Focus Dalam Penanganan Pasca Bencana Tahap Rehabilitasi", (Studi Kasus pada Peristiwa Gempa Bumi di Klaten, 27 Mei 2006). WARTA, Vol .10, No. 1, Maret 2007: 43 - 52. Universitas Muhammadiyah Surakarta, 2007.

[9] Badan Meteorologi, Klimatologi, Dan Geofisika (BMKG). https://www.bmkg.go.id/press-release/?p=gempa-susulanm6-5-kembali-guncang-pulau-lombok-tidak-berpotensi- tsunami\&tag=press-release \&lang=ID Diakses 28 September 2018.

[10] M. I. C. Marchiavelly, L. Narieswari, S. L. Munajati, Sumaryono., W. E. Santoso, and S. Martha, "Pemetaan Risiko Bencana Pada Daerah Pariwisata Kabupaten Lombok Barat, Nusa Tenggara Barat" (Hazard Risk Mapping on Tourism Region of West Lombok Regency, West Nusa Tenggara). Globe Volume 14 No. 2 Desember 2012 : 187 199, 2012.

[11] M. A. Kurniawan, K. N. Suarbawa, A. Septiadhi, "Analisis Risiko Bencana Gempabumi di Wiliyah Nusa Tenggara Barat", Buletin Fisika Vol 18 No.1 Pebruari 2017 : 38 - 45. Universitas Udayana, 2017

[12] W. N. Carter, "Manajemen Penanggulangan Bencana, Perpustakaan Nasional Data CIP”. Manila, Philipina., 1991.

[13] Undang-Undang R.I. Nomor 24 Tahun 2007 tentang Penanggulangan Bencana. Jakarta: BAKORNAS PB, 2007.

[14] G. F. White, and J.E. Haas, "Assessment of Research on Natural Hazards", Cambridge, MA: MIT Press, 1975.

[15] K. Hewitt, "Regions of Risk: a geographical introduction to disasters", Essex, Addison Wesley Longmann, 1997.

[16] D. S. Mileti, "Disasters by Design: A Reassessment of Natural Hazards in the United States", Washington, DC: Joseph Henry Press, 1999.

[17] D. Alexander, "Confronting Catastrophe: New Perspectives on Natural Disasters". New York, NY: Oxford University Press, 2000.

[18] S. L. Cutter, J. T. Mitchell, M. S. Scott, "Revealing the Vulnerability of People and Places: A Case Study of George Town County", South Carolina. Annals of the Association of American Geographers, 90(4), p. 713-737. Blackwell Publishers, 2000

[19] R. W. Kates, "Human adjustment. In T en Geographic Ideas that Changed the World", edited by S. Hanson. New Brunswick, New Jersey: Rutgers University Press), pp. 87107, 1996.

[20] C. Benson, "Macro-Economic Concepts of Vulnerability: Dynamics, Complexity and Public Policy", In Mapping Vulnerability: Disasters, Development and People, G. Bankoff, G. Frerks, and D. Hilhorst, 159-173. Earthscan: London, 2008.

[21] LIPI-UNESCO/ISDR. Kajian Kesiapsiagaan Masyarakat dalam Mengantisipasi Bencana Gempa Bumi dan Tsunami, http://lipi.go.id/berita/laporan-kajian-kesiapsiagaanmasyarakat-unesco-lipi/759 Diakses 08 September 2018

[22] H. P. Rahayu, and M. Aria, "Pedoman Pelaksanaan Latihan Kesiapsiagaan Bencana Tsunami (Tsunami Drill)”. Jakarta: Diterbitkan oleh Kementerian Negara Riset dan Teknologi (KNRT, tahun 2007) xxi + 109 halaman ; $20 \mathrm{~cm}$ x $22 \mathrm{~cm}$., 2007.

[23] Muhaimin, B. Tjahjono, and Darmawan, "Analisis Risiko Gempabumi di Cilacap Provinsi Jawa Tengah", Alumni Program Studi Mitigasi Bencana dan Kerusakan Lahan, Sekolah Pascasarjana, Institut Pertanian Bogor dan Departemen Ilmu Tanah dan Sumberdaya Lahan, Fakultas Pertanian IPB. Jurnal Ilmu Tanah Lingkungan 18 (1) April 2016: 28-34. ISSN 1410-733, 2016

[24] Setyaningrum, et al. "Persepsi Masyarakat tentang Mitigasi Bencana Kegempaan di Kecamatan Pleret, Kabupaten Bantul". Tesis S-2. Yogyakarta: Program Pasca Sarjana. Fakultas Teknik Sipil dan Perencanaan Universitas Islam Indonesia. (2010)

[25] T. Rashed, and J. Weeks, "Assessing vulnerability to earthquake hazards through spatial multicriteria analysis of urban areas" International Journal of Geographical Information Science 2003 VOL. 17, NO 6, 547-576. 2010.

[26] Darmanto. "Pengalaman dari Penanganan Bencana Alam di Yogyakarta.". Makalah RAPI V. Surakarta: Fakultas Teknik UMS. "Dalam Prosiding Simposium Nasional RAPI V2006 FT UMS", 2006. 
[27] Subandono. "Program Mitigasi Bencanabdalam Zone Perairan Laut", Jakarta: Departemen Kelautan Republik Indonesia, 2007.
[28] D. Suhardjo, "Arti Penting Pendidikan Mitigasi Bencana Dalam Mengurangi Resiko Bencana", Cakrawala Pendidikan, Juni 2011, Th. XXX, No. 2, 2011 